Research

\title{
Comparison of Fluticasone Furoate and Cetirizine Versus Fluticasone Furoate and Montelukast in Allergic Rhinitis
}

\author{
Bobby Pardomuan Sitompul, Rus Suheryanto, Hendradi Surjotomo \\ Department of Otorhinolaryngology Head and Neck Surgery \\ Faculty of Medicine, Brawijaya University / Dr. Saiful Anwar General Hospital, \\ Malang
}

\begin{abstract}
Background: The complexity of treatment in allergic rhinitis remains to be a global challenge. The medical treatment option for moderate-severe persistent allergic rhinitis is the combination of intranasal corticosteroid (INCS) and oral antihistamine or leukotriene receptor antagonist (LTRA). The combination INCS with LTRA is selected based on the presence of asthma. Purpose: To determine the effect of fluticasone furoate plus cetirizine administration compared to fluticasone furoate plus montelukast on nasal eosinophils count and clinical improvement in patients with moderate-severe persistent allergic rhinitis. Method: This study was an experimental research with double blind randomized clinical trial (RCT) design, and pre and post test control. Patient were divided into two group. Group-1 received intranasal fluticasone furoate $110 \mu \mathrm{g}$ in the morning and oral cetirizine $10 \mathrm{mg}$ in the evening, and group-2 received intranasal fluticasone furoate $110 \mu \mathrm{g}$ and montelukast 10mg. The treatment efficacy was assessed from nasal eosinophil count and total five symptoms score (T5SS) based on visual analogue scale (VAS) before and 4 weeks after treatment. Result: Both groups showed a decrease in the nasal eosinophil count and T5SS score based on VAS before and after treatment $(p<0.05)$. Group-2 showed a statistically significant improvement in nasal obstruction and rhinorrhea compared to group-1 $(\mathrm{p}<0.05)$. The decrease in nasal eosinophil count and T5SS was higher in group-2 than group-1, however it is not statistically significant. Conclusion: The combination of fluticasone furoate and montelukast was found to be more effective in reducing nasal obstruction and rhinorrhea than the combination of fluticasone furoate and cetirizine
\end{abstract}

Keywords: allergic rhinitis, cetirizine, intranasal corticosteroid, montelukast

\begin{abstract}
ABSTRAK
Latar belakang: Rinitis alergi masih merupakan masalah besar secara global dengan tatalaksana yang kompleks. Terapi medikamentosa rinitis alergi persisten sedang berat (RAPSB) berdasarkan guideline yaitu pemberian kortikosteroid intranasal (INCS) dikombinasikan dengan antihistamin oral atau leukotriene receptor antagonist (LTRA). Saat ini, terapi menggunakan kombinasi LTRA masih berdasarkan ada atau tidaknya komorbiditas asma pada pasien RAPSB. Tujuan: Mengetahui pengaruh pemberian fluticasone furoate bersama cetirizine dibandingkan dengan fluticasone furoate bersama montelukast terhadap eosinofil mukosa hidung dan perbaikan klinis pada penderita RAPSB. Metode: Penelitian eksperimental murni dengan rancangan uji klinik secara acak, tersamar ganda, serta kontrol pra dan pasca perlakuan. Penderita dibagi menjadi 2 kelompok. Kelompok 1 mendapat terapi fluticasone furoate intranasal $110 \mu \mathrm{g} /$ hari dengan cetirizine $10 \mathrm{mg} /$ hari dan kelompok 2 fluticasone furoate intranasal $110 \mu \mathrm{g} /$ hari dengan montelukast $10 \mathrm{mg} /$ hari. Penilaian efektivitas terapi dengan menilai jumlah eosinofil mukosa hidung dan total five symptoms score (T5SS) berdasarkan visual analogue scale (VAS) pada awal penelitian dan 4 minggu setelah perlakuan. Hasil: Kedua kelompok memperlihatkan penurunan jumlah eosinofil mukosa hidung dan penurunan T5SS berdasarkan VAS antara sebelum dan setelah perlakuan $(p<0.05)$. Kelompok 2 lebih baik secara bermakna menurunkan keluhan hidung tersumbat dan pilek encer dibandingkan kelompok 1 ( $p<0.05)$. Jumlah eosinofil dan T5SS berdasarkan VAS kelompok 2 lebih menurun dibandingkan kelompok 1, akan tetapi secara statistik
\end{abstract}


tidak terdapat perbedaan yang bermakna. Kesimpulan: Pemberian fluticasone furoate serta montelukast lebih baik secara bermakna menurunkan keluhan hidung tersumbat dan pilek encer dibandingkan pemberian fluticasone furoate serta cetirizine.

Kata kunci: rinitis alergi, cetirizine, kortikosteroid intranasal, montelukast

Correspondence address: Bobby Pardomuan Sitompul, Department of Oto Rhino Laryngology-Head and Neck Surgery, Faculty of Medicine, Brawijaya University / Dr. Saiful Anwar General Hospital, Malang. Email:bobbypardo2408@gmail.com.

\section{INTRODUCTION}

Allergic rhinitis (AR) is clinically defined as a symptomatic disorder of the nose induced after allergen exposure by an IgE-mediated inflammation. The classic symptoms of AR are nasal itching, sneezing, rhinorrhea, and nasal congestion. Additionally, ocular symptoms frequently accompany the main symptoms as it can be seen in allergic rhinoconjunctivitis which is associated with itching and redness of the eyes and tearing. The other symptoms include itching of the palate, postnasal drip and cough. Allergic rhinitis is a global health problem that causes major illness and disability worldwide. Patients from various countries, ethnicity and ages suffer from allergic rhinitis. It affects their social and daily activities. Although, allergic rhinitis does not increase the direct costs for healthcare, however, the indirect costs are somewhat increased. ${ }^{1}$

The prevalence of AR has been estimated to be approximately 2 to $25 \%$ in children and 1 to over $40 \%$ in adults, and confirmed AR in adults in Europe ranged from $17 \%$ to $28.5 \%$. Recent studies showed that the prevalence of AR had increased, in particular in countries with initialy low prevalence. AR is also frequently associated with asthma which is found in $15 \%$ to $38 \%$ of patients with allergic rhinitis and that nasal symptoms are present in $6 \%$ to $85 \%$ patients with asthma. ${ }^{2}$

The complexity of the treatment remains to be a global challenge. The medical treatment option for moderate severe persistent allergic rhinitis is the combination of intranasal corticosteroid (INCS) and oral antihistamine or leukotriene receptor antagonist (LTRA). The combination of LTRA is selected based on the presence of asthma. ${ }^{1,2}$ The nasal steroids can reduce nasal congestion and recommended as the first-line treatment in allergic rhinitis patients with moderate to severe and persistent symptoms. ${ }^{3}$ The efficacy of topical nasal corticosteroids depends on compliance, and maximum efficacy is usually apparent after 1-2 weeks. Oral antihistamines improve rhinorrhea, sneezing, itching and eye symptoms, but they are relatively less effective for nasal congestion and inflammation. The leukotriene receptor antagonists that were recently introduced in the treatment of allergic rhinitis also have beneficial effects in management. The role of LTRA in treating asthma and AR is thought to be related to its impact on the leukotriene pathway of allergic inflammatory cascade. ${ }^{4}$

The aim of this study was to compare the effects between the combination of fluticasone furoate and cetirizine and the combination of fluticasone furoate and montelukast in reducing the eosinophil count and total five symptoms score (T5SS) based on the Visual Analogue Scale (VAS) before and 4 weeks after treatment.

\section{METHOD}

Patients with moderate to severe persistent allergic rhinitis were recruited from the 
ENT outpatient clinic of Dr. Saiful Anwar Hospital, Malang. Patients were excluded if they were taking the following drugs: antihistamine, corticosteroids (inhaled, intranasal, or systemic), or inhaled sodium cromoglycate within the past 4 weeks. Other exclusion criteria were the presence of concurrent infection of the paranasal sinuses, and/or of the upper or lower respiratory tract, asthma, structural nasal abnormalities or concurrent diseases that could interfere with the validity of the study results, including autoimmune disease and malignancy. Patients were also excluded if they were pregnant or lactating. Written informed consent was obtained from all enrolled patients. The study was approved by the Ethic Committees of Dr. Saiful Anwar Hospital.

This study is a double blind, randomized clinical trial with pre and post- test control. The patients were randomly allocated into two groups. The Group-1 received intranasal fluticasone furoate $110 \mu \mathrm{g}$ once daily in the morning and oral cetirizine $10 \mathrm{mg}$ in the evening, while, group-2 received intranasal fluticasone furoate $110 \mu \mathrm{g}$ once daily in the morning and oral montelukast $10 \mathrm{mg}$ in the evening. The nasal eosinophil count and the total five symptoms score (T5SS) were measured before treatment and 4 weeks after treatment.

\section{Total Five Symptoms Score (T5SS)}

T5SS evaluated in this study were rhinorrhea, sneezing, nasal obstruction, nasal itching and eye symptoms (itching and redness of the eyes and tearing). Each symptom was evaluated individually and the total five symptom score was calculated as the sum of five symptoms. Symptoms were scored based on VAS (0-10) as follows; nasal congestion: 0 -free breathing; 10-complete obstruction at day and night; rhinorrhoea: 0-dry nose all day; 10-continuous secretion (wiping the nose many times in one hour); nasal itching: 0-no itching; 10-persistent itching disrupting daily activities; sneezing: 0-no sneezing; 10 -persistent sneezing fits for the whole day and night that disrupt normal functioning; eye symptoms: 0-no itching, redness and tearing; 10-persistent itching, redness and tearing disrupting daily activities. The total possible five symptom score was 50 .

\section{Nasal Smear eosinophilia}

Nasal smears were studied for eosinophilia. The smears were collected by scraping the mucous membrane of the inferior meatus with a blunt applicator, air-dried, stained with May Grunwald-Giemsa (MGG) stain and rinsed in tap water. All cytograms were encoded and read by a single-blinded investigator using light microscope. The smear was considered positive for eosinophils if the number of eosinophils was more than $10 \%$ of the total leukocytes.

The data were analysed using the SPSS 25 for Windows. A p-value less than 0.05 were considered statistically significant.

\section{RESULT}

A total of twenty patients were randomly allocated to treatment groups consisted of ten patients for each group. All patients completed the whole study, including the follow-up period. The sociodemographic characteristics were shown in Table 1 . The baseline clinical characteristics, duration of disease, mean nasal smear eosinophil count and mean T5SS were shown in Table 2.

Table 1. Sociodemographic

\begin{tabular}{lcc}
\hline $\begin{array}{c}\text { Characteristics } \\
(\mathbf{N = 1 2 )}\end{array}$ & $\begin{array}{c}\text { Group-1 } \\
\mathbf{n}(\mathbf{\%})\end{array}$ & $\begin{array}{c}\text { Group-2 } \\
\mathbf{n}(\mathbf{\%})\end{array}$ \\
\hline Age, mean \pm SD (years) & $29.7 \pm 5.27$ & $31.2 \pm 3.88$ \\
Age & & \\
$<26$ years & $2(20)$ & $0(0)$ \\
26 - 30 years & $4(40)$ & $4(40)$
\end{tabular}




\begin{tabular}{lcc}
$31-35$ years & $3(30)$ & $4(40)$ \\
$36-40$ years & $1(10)$ & $2(20)$ \\
\hline Sex & $5(50)$ & $6(60)$ \\
Male & $5(50)$ & $4(40)$ \\
Female & & \\
Occupation & $8(80)$ & $10(100)$ \\
Employed & $2(20)$ & $0(0)$ \\
$\quad$ Unemployed & &
\end{tabular}

Table 2. Clinical characteristic at baseline of participants

\begin{tabular}{lcc}
\hline \multicolumn{1}{c}{$\begin{array}{c}\text { Characteristics } \\
(\mathbf{N}=\mathbf{1 2})\end{array}$} & $\begin{array}{c}\text { Group-1 } \\
\mathbf{n}(\mathbf{\%})\end{array}$ & $\begin{array}{c}\text { Group-2 } \\
\mathbf{n}(\mathbf{\%})\end{array}$ \\
\hline Disease duration, mean \pm SD (year) & $11.45 \pm 5.5$ & $14.8 \pm 4.5$ \\
Disease duration & & \\
$<5$ years & $1(10)$ & $0(10)$ \\
5 -9 years & $2(20)$ & $0(10)$ \\
$\geq 10$ years & $7(70)$ & $10(100)$ \\
Nasal eosinophil count, mean \pm SD & $18.3 \pm 7.2$ & $24.1 \pm 14.4$ \\
T5SS, mean \pm SD & $30 \pm 10.8$ & $31.9 \pm 9.1$ \\
Symptoms & & \\
Nasal congestion & $10(100)$ & $10(100)$ \\
Rhinorrhea & $10(100)$ & $10(100)$ \\
Sneezing & $10(100)$ & $10(100)$ \\
Nasal itching & $9(90)$ & $10(100)$ \\
Eye symptoms & $10(100)$ & $10(100)$ \\
Family History of allergies & & $7(70)$ \\
Positive & $9(90)$ & $3(30)$ \\
\hline Negative & $1(10)$ & \\
\hline
\end{tabular}

$\mathrm{SD}=$ standard deviation

Table 3. The comparison of the nasal smear eosinophil count between group-1 and group-2 before and after treatment

\begin{tabular}{lccc}
\hline Nasal Smear Eosinophil & Group-1 & Group-2 & \multirow{2}{*}{ P-value } \\
\cline { 2 - 3 } \multicolumn{1}{c}{ Count } & \multicolumn{2}{c}{ (mean \pm SD) } & \\
\hline Before treatment & $18.3 \pm 7.23$ & $24.1 \pm 14.44$ & 0.276 \\
After treatment & $3.4 \pm 2.84$ & $1.8 \pm 1.4$ & 0.127 \\
\hline
\end{tabular}

There was a significant difference in the nasal smear eosinophil count before and after treatment in group-1 and group-2 with a $\mathrm{p}$ value $<0.05$. The independent t-test between group- 1 and group- 2 before and after treatment showed no significant difference, with $p$ value $>0.05$. (Table 3 )

After receiving therapy, it was found that all study subjects experienced a decrease in T5SS in both treatment groups. (Figure 1)

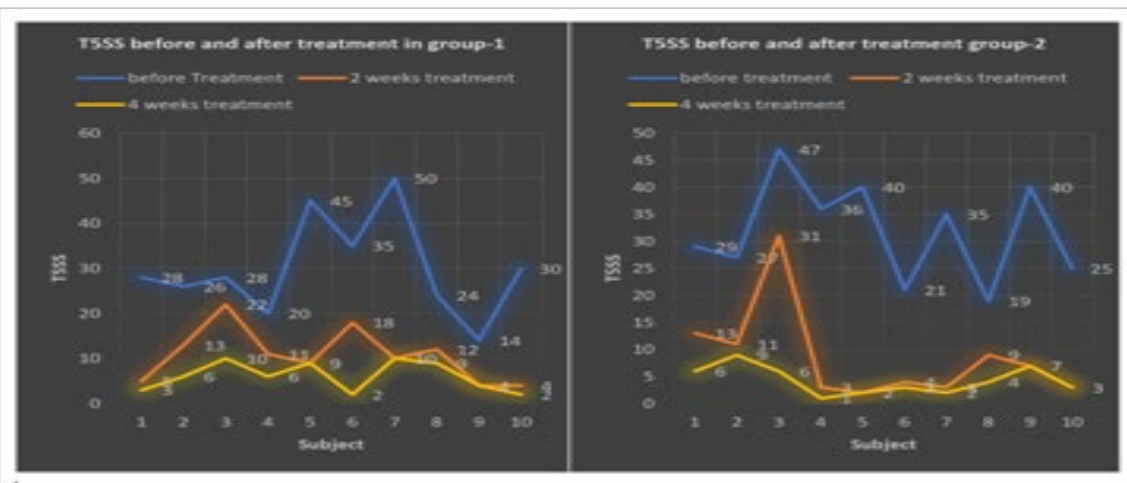

Figure 1. Differences T5SS before, 2 weeks and 4 weeks after treatment in the group-1 and group- 2 . 
Table 4. The comparison in T5SS score between the group 1 and group 2 before, 2 weeks after and 4 weeks after treatment

\begin{tabular}{lccc}
\hline \multirow{2}{*}{ T5SS } & \multicolumn{1}{c}{ Group-1 } & Group-2 & \multirow{2}{*}{ P-value } \\
\cline { 2 - 3 } & \multicolumn{2}{c}{ (mean \pm SD) } & \\
\hline Before treatment & $30 \pm 10.88$ & $31.9 \pm 9.13$ & 0.677 \\
After treatment & $10.8 \pm 5.90$ & $8.60 \pm 8.76$ & 0.518 \\
2 weeks & $6.1 \pm 3.25$ & $4.2 \pm 2.58$ & 0.187 \\
4 weeks & & &
\end{tabular}

Table 5. The comparison of symptoms base on VAS before and after treatment between group-1 and group-2

\begin{tabular}{lccc}
\multicolumn{1}{c}{ Symptoms } & Group-1 & Group-2 & \multirow{2}{*}{ P-value } \\
\cline { 2 - 3 } & \multicolumn{2}{c}{ (mean \pm SD) } & \\
\hline Before treatment & & & 0.06 \\
Nasal congestion & $5.7 \pm 2.71$ & $7.6 \pm 1.43$ & 0.418 \\
Rhinorrhea & $6.1 \pm 2.23$ & $6.9 \pm 2.08$ & 0.914 \\
Sneezing & $6.6 \pm 2.22$ & $6.7 \pm 1.83$ & 0.337 \\
Nasal itching & $6.3 \pm 2.31$ & $5.2 \pm 2.66$ & 0.881 \\
Eye symptoms & $5.3 \pm 2.75$ & $3.1 \pm 3.14$ & $\mathbf{0 . 0 2 8 *}$ \\
After treatment & & & $\mathbf{0 . 0 1 7 *}$ \\
Nasal congestion & $2.2 \pm 1.57$ & $0.9 \pm 0.99$ & 0.673 \\
Rhinorrhea & $1.6 \pm 0.84$ & $0.7 \pm 0.68$ & 0.409 \\
Sneezing & $1.2 \pm 1.23$ & $1.0 \pm 0.82$ & 0.24 \\
Nasal itching & $0.9 \pm 0.88$ & $0.6 \pm 0.7$ & $1.1 \pm 1.37$ \\
Eye symptoms & $0.5 \pm 0.71$ & & \\
\hline Fignifint & & &
\end{tabular}

*Significant $\mathrm{p}$ value; $\mathrm{SD}=$ standard deviation

There was a significant difference in T5SS between before and after treatment in both groups with a p-value $<0.05$. While the decrease of T5SS between group-1 and group-2 showed no significant difference in either before or after treatment ( $p$ value $>$ 0.05). (Table 4)

There were significant difference in all symptoms before and after treatment with $p$ value $<0.05$ for both groups. Group- 2 showed a statistically significant improvements in nasal obstruction and rhinorrhea compared to group-1 $(\mathrm{p}<0.05)$. The other symptoms between group 1 and group-2 had no significant differences with $p$ value $>0.05$ in either before and after treatment. (Tabel 5)

There was no significant correlation between nasal eosinophil smear and T5SS ( $p>0.05$ ) between group- 1 and group- 2 before and after treatment.

\section{DISCUSSION}

The age of the participants in this study mostly were between 26-30 years old. This finding was similar with the other studies that found the highest incidence was between the ages of 17 to 34 years. ${ }^{5}$ The mean age of the participants in our study was $30.45 \pm 4.57$ years old. Similar findings were found in other studies, with the mean age of $31.8 \pm$ 9.6 years and $33.8 \pm 12.0$ years. ${ }^{6}$ Female to male gender ratio in this study was 1.22:1. In The United State of America, the sex ratio of allergic rhinitis was almost similar. ${ }^{5}$ Moreover, based on the meta-analysis, there was no evidence of sex predominance in allergic rhinitis, especially in adults. ${ }^{7}$ Almost $90 \%$ of the study participants were employed. This reflected of the high prevalence of allergic rhinitis in adults. They are the most productive population which is more vulnerable to allergen exposure and high humidity environment. This working age populatin tends to seek healthcare for their 
allergic related symptoms which interferes their productivity. ${ }^{2}$

This study showed that all of the participants suffered nasal congestion, rhinorrhea, sneezing, and about 95\% participants had itchy nose. These symptoms are the manifestation of allergic rhinitis. All of the subjects suffered those symptoms more than 4 days in a week, and in the duration more than 4 weeks. These symptoms affected their daily activities and causing sleep disorder. These qualified the criteria of moderate severe persistent allergic rhinitis. ${ }^{1,2}$

The duration of allergic rhinitis symptoms in this study was more than 10 years. This finding supported other studies that reported the onset of allergic rhinitis symptoms was more than 10 years, and highest among those aged around 30 years old. ${ }^{2,5}$ A study in Egypts showed that most of allergic rhinitis patients had experienced 7-10 years of allergic rhinitis symptoms before the examination. ${ }^{8}$

In our study, around $80 \%$ of the participants had a family history of allergy, and the rest (20\%) did not have atopy but they were experiencing allergic rhinitis symptoms. The genes associated with atopy were found on the $3 q 21,5 q 31-q 33,7 p 14-p 15$, and 14q24 which caused two-fold increase in the risk of allergic rhinitis. ${ }^{9}$ There was a research that showed the risk of allergic rhinitis in a child with family history of allergy in both of the parents, one of the parents, and none of the parents were $60 \%, 20 \%$ and $10 \%$, respectively. ${ }^{10}$ This explains that patients without history of allergies could still have allergic rhinitis.

In our study, all of the participants had a positive eosinophil nasal smear count with average count of $21.1 \pm 11.51$ before treatment. The eosinophil plays a role in allergic rhinitis, especially in the sputum smear, that suggest an association with non-specific airway hyperresponsiveness without inducing asthma symptoms. ${ }^{11}$ The nasal smear cytology, could be used as a substitute for sputum cytology test to assess the inflammation of the lower respiratory tract. ${ }^{12}$ Other study showed that around $80 \%$ of positive eosinophil nasal smear in allergic rhitinis was found to have moderate eosinophilic expression (10-50). ${ }^{13}$

The mean T5SS score before treatment in our study was $30.95 \pm 9.83$, with the average VAS score equal to 6 for each symptom. Similar findings were found in other studies showing an average VAS score of $6.09 \pm$ 1.98. ${ }^{14}$ However, there has been no studies that combined the VAS with T5SS score. The study in France showed that the drug efficacy in intermitten allergic rhinitis used different VAS scoring for each symptoms. ${ }^{6}$ Thus, this study could not be compared directly.

In our study, there was a significant difference in the nasal smear eosinophil count between the group-1 and group-2 before and after treatment $(\mathrm{p}<0.05)$. The nasal smear eosinophil count was observed to be lower in group-2 than group-1. However, the difference was not statistically significant with a p-value of 0.127 . These findings were also observed in other studies showing no significant difference between the combination of fluticasone propionate plus cetirizine and the combination of fluticasone propionate plus montelukast. The infiltration of eosinophil on nasal mucosa after allergen exposure plays a major role in allergic rhinitis. Moreover, the eosinophil became the major source of LTC4, tromboxane $\mathrm{A} 2$, and platelet activating factor that contributed to late phase inflammation and the hyperresponsiveness of nasal mucosa. ${ }^{15}$ The intranasal corticosteroids, especially fluticasone furoate, inhibit the transcription of IL-5, IL-13, eotaxin, ICAM-1, and eosinophil migration in nasal mucosa. ${ }^{16,17}$ The significant decrease in the eosinophil count before and after treatment with intranasal corticosteroid was also observed in other study. ${ }^{16}$

Cetirizine was found to have lower effect to inflammation in nasal mucosa than montelukast. ${ }^{18}$ In this research there was no 
difference of eosinophil count in the nasal mucosa between the fluticasone furoate plus cetirizine and the fluticasone furoate plus montelukast. This fact could be caused by the intranasal corticosteroids given to both treatment groups. Moreover both treatment combinations were effective in improving the clinical symptoms after 2-weeks and 4-weeks treatment, with lower T5SS score in the combination of intranasal steroids with montelukast. This finding was similar with other research that showed a significant improvement in total nasal symptoms score before and after treatment compared to placebo. ${ }^{16}$ While other research showed a combination of intranasal corticosteroid and desloratadine had lower T5SS score at 2-weeks after treatment, the combination with montelukast showed to be better at 4-weeks after treatment. ${ }^{18}$

Our study showed that the combination of fluticasone furoate and montelukast was significantly improved the nasal congestion and rhinorrhea $(\mathrm{p}<0.05)$. Similar finding was found in other research showing the improvement in the quality of life after treatment with intranasal mometasone furoate and montelukast. ${ }^{3}$ Moreover, the combination of INCS with montelukast as treatment in allergic rhinitis with asthma could reduce the bronchoconstriction. ${ }^{4}$ The antihistamine treatment does not affect asthma, anyhow it is still beneficial for comprehensive management of united airway disease. ${ }^{19}$ In contrast, there was a study that showed no significant difference in nasal congestion symptom between montelukast and cetirizine treatment. ${ }^{16}$ But this research had a different study population of patients with intermittent allergic rhinitis.

The improvement in the rhinorrhea symptom was observed to be better in combination of fluticasone furoate and montelukast than fluticasone furoate fluticasone furoate and cetirizine. Montelukast inhibits cysteinyl leukotriene receptor 1
(CysLT1) and CysLT2 in nasal vascularization and glands. ${ }^{15}$ Nevertheless, other study showed that rhinorrhea symptom was better reduced with the combination of mometasone furoate and levocetirizine. ${ }^{3}$ In fact, that study used different evaluation system and VAS scoring. Hence, this explained why it showed a different result from our study.

Our study showed there was no correlation between T5SS and VAS score before and after treatment. There was no study yet that disclosed the correlation of T5SS and nasal smear eosinophil count. However, there was a correlation between the clinical symptoms and immunology parameter in allergic rhinitis. ${ }^{20}$ Therefore, there is a need for further research to evaluate this association.

In conclusion, the combination of fluticasone furoate and montelukast was significantly reduced nasal congestion and rhinorrhea based on VAS compared to the combination of fluticasone furoate and cetirizine. Both treatment effectively reduced nasal mucosa eosinophil and improved the quality of life in moderate to severe persistent allergic rhinitis patients. These treatments could provide effective therapy in allergic rhinitis based on patients' preferences, dominant symptoms and cost efficiency.

\section{REFERENCE}

1. Bousquet J, Khaltaev N, Cruz AA, Denburg J, Fokkens W, Togias A, et al. Allergic rhinitis and its impact on asthma (ARIA) 2008. Allergy. 2008; 63 (Suppl.86): 8-160.

2. Brożek JL, Bousquet J, Agache I, Agarwal A, Bachert C, Bosnic-Anticevich S, et al. Allergic Rhinitis and its Impact on Asthma (ARIA) guidelines - 2016 revision. J Allergy Clin Immunol. 2017; 140(4): 950-8.

3. Tatar E, Surenoglu U, Ozdek A, Saylam G, Korkmaz H. The effect of combined medical treatment on quality of life in persistent allergic rhinitis. Indian J otolaryngol head neck surg. 2013; 65(Suppl.2): 333-7. 
4. Price DB, Swern A, Tozzi C, Philip G, Polos P. Effect of montelukast on lung function in asthma patients with allergic rhinitis: analysis from the COMPACT trial. Allergy. 2006; 61(6): 737-42.

5. Nathan R, Meltzer EO, Selner JC, Stroms W. Prevalence of Allergic Rhinitis in the United States J Allergy Clin Immunol. 1997; 99(6): 808-14.

6. Bousquet J, Bachert C, Canonica G, Mullol $\mathrm{J}$, Van Cauwenberge P, Bindslev Jensen C, et al. Efficacy of desloratadine in intermittent allergic rhinitis: a GA2 ${ }^{2} \mathrm{LEN}$ study. Allergy. 2009; 64(10): 1516-23.

7. Pinart M, Keller T, Reich A, Fröhlich M, Cabieses B, Hohmann C, et al. Sex-Related Allergic Rhinitis Prevalence Switch from Childhood to Adulthood: A Systematic Review and Meta-Analysis. Int Arch Allergy Immunol. 2017; 172(4): 224-35.

8. Abdel-hamid HM, Abdel-Rehim AS, Mahmoud NA, Fattah MFA, Hussein AY. Relation between nasal eosinophilia and airway resistance in patients with persistent rhinitis. Egypt J Chest Dis Tuberc. 2018; 67(2): 191-4.

9. Utama DS. Hubungan Antara Jenis Aeroalergen dengan Manifestasi Klinis Rinitis Alergika. Tesis. Semarang; Fakultas Kedokteran Universitas Diponegoro; 2010.

10. Koning A, Baert M, Oranje A. Development of Immune Functions Related to Allergic Mechanisms in Young Children. Pediatr Res. 1996; 40(3): 363-75.

11. Yang M-S, Lee H-S, Kim M-H, Song W-J, Kim T-W, Kwon J-W, et al. Rhinitis patients with sputum eosinophilia show decreased lung function in the absence of airway hyperresponsiveness. Allergy Asthma Immunol Res. 2013; 5(4): 232-8.

12. Amorim M, Araruna A, Caetano L, Cruz A, Santoro L, Fernandes A. Nasal eosinophilia: an indicator of eosinophilic inflammation in asthma. Clin Exp Allergy. 2010; 40(6): 867-74.

13. Sood A. Diagnostic Significance of Nasal Eosinophilia in Allergic Rhinitis. Indian J Otolaryngol Head Neck Surg. 2005; 57(1): 13-6.

14. Demoly P, Bousquet P, Mesbah K, Bousquet $\mathrm{J}$, Devillier P. Visual analogue scale in patients treated for allergic rhinitis: an observational prospective study in primary care. Clin Exp Allergy. 2013; 43(8): 881-8.

15. Sin B, Togias A. Pathophysiology of Allergic and Nonallergic Rrhinitis. Proc Am Thorac Soc. 2011; 8(1): 106-14.

16. Di Lorenzo G, Pacor MI, Pellitteri ME, Morici G, Di Gregoli A, Lo Bianco C, et al. Randomized placebo-controlled trial comparing fluticasone aqueous nasal spray in mono-therapy, fluticasone plus cetirizine, fluticasone plus montelukast and cetirizine plus montelukast for seasonal allergic rhinitis. Clin Exp Allergy. 2004; 34(2): 259-67.

17. Anolik R. Fluticasone furoate nasal spray: Profile of an enhanced-affinity corticosteroid in treatment of seasonal allergic rhinitis. $\mathrm{J}$ Asthma Allergy. 2010; 3: 87-99.

18. Pinar E, Eryigit O, Oncel S, Calli C, Yilmaz $\mathrm{O}$, Yuksel H. Efficacy of nasal corticosteroids alone or combined with antihistamines or montelukast in treatment of allergic rhinitis. Auris Nasus Larynx. 2008; 35: 61-6.

19. Compalati E, Ridolo E, Passalacqua G, Braido F, Villa E, Canonica GW. The link between allergic rhinitis and asthma: the united airways disease. Expert Rev Clin Immunol. 2010; 6(3): 413-23.

20. Ciprandi G, Vizzaccaro A, Cirillo I, Tosca M, Massolo A, Passalacqua G. Nasal Eosinophils Display the Best Correlation with Symptoms, Pulmonary Function and Inflammation in Allergic Rhinitis. Int Arch Allergy Immunol. 2005; 136(3): 266-72 